ROCZNIKI NAUK PRAWNYCH

Volume XXVIII, number $3-2018$

E n g $1 \mathrm{ish}$ ver s i o n

DOI: http://dx.doi.org/10.18290/rnp.2018.28.3-1en

\title{
INTRODUCTION OF THE CONCEPT OF AN INDEPENDENT CENTRAL BANK INTO THE POLISH POLITICAL SYSTEM IN LIGHT OF THE EUROPEAN EXPERIENCE
}

\section{INTRODUCTION}

There seems to exist a sort of consensus on the position of the central bank in a democratic institutional system. There is no doubt that the solutions used in various countries are different, but what links them is a clear emphasis on the independence and separation of the central bank from the traditional executive bodies. This article briefly describes the development of central banking with regard to its independence, with special focus on the way the idea of an independent central bank was implemented in Poland, but for the sake of presentation we will use a broader background of EU solutions and selected European countries.

In the first part, we will attempt to provide a theoretical description of central-bank independence and show its various aspects. Next, the evolution of the position of selected central banks will be outlined. This will provide a historical backdrop for the third, main part of the study, to demonstrate how the idea of central-bank independence has been implemented systemically,

REMIGIUSZ ChĘCIŃSKI, MA, is a doctoral student at the Department of Competition Law and Sector-Specific Regulation, Faculty of Law, Administration and Economics, University of Wrocław; address: ul. Uniwersytecka 22/26, 50-145 Wrocław, Poland; e-mail: remik.checinski@ gmail.com; https://orcid.org/0000-0003-0523-8045.

Michae PrZychodzKi is a student of Inter-area Individual Humanistic and Social Studies, Adam Mickiewicz University in Poznań; address: ul. Fredry 10, 61-717 Poznań, Poland; e-mail: m_przychodzki@wp.pl; https://orcid.org/0000-0002-2217-3346. 
with special regard to the regulations used in Poland. Importantly, however, the position of the Polish central bank did not evolve in isolation but was a reflection of processes taking place in an international forum.

\section{THE CONCEPT OF CENTRAL-BANK INDEPENDENCE}

In the most general terms, the concept of independence implies separation of the central bank from the state authorities. This concept is multi-faceted, and there are different theoretical approaches to central-bank independence. At the most general level, we can distinguish political independence associated with the establishment of monetary policy objectives and economic independence concerning the choice of means of its implementation. ${ }^{1}$ Within the sphere of independence, much importance is attached to relations with the country's government. ${ }^{2}$ An independent central bank cannot be subordinated to the executive authority. Also the importance of the ban on the financing of budgetary expenditure by the central bank is highlighted, as it restricts the possibility of the government putting pressure. It seems that the most operative and common way of characterizing central-bank independence in theoretical terms is to define its three dimensions: personal, financial and functional. ${ }^{3}$

First of all, personal independence involves the reduction to a minimum of the influence the government and the Minister of Finance have on staffing in the bank's governing bodies. This independence is safeguarded by: rotation of terms of office and irrevocability of the office holders, cooperation of representatives of various authorities and having a qualified majority when appointing (and dismissing) members of the governing bodies, the principle of incompatibility with other public positions, prohibition to conduct other activities, membership in a political party or trade union, and finally substantial salaries. The possibility of dismissal is in practice limited to objective cases only, such as an intentional offence subject to public prosecution or the incapacity of continuing the office.

\footnotetext{
${ }^{1}$ P. MARSZAŁEK, Koordynacja polityki pieniężnej i fiskalnej jako przestanka stabilności cen (Warszawa: Wydawnictwo Naukowe PWN, 2009), 73.

${ }^{2}$ A. BLINDER, Bankowość centralna w teorii i praktyce (Warszawa: Wydawnictwo: CeDeWu, 2001), 84-86.

${ }^{3}$ See E. MYŚlaK, Narodowy Bank Polski w systemie ustrojowym Rzeczypospolitej Polskiej (Kraków: Wydawnictwo Uniwersytetu Jagiellońskiego, 2013), 138-39.
} 
The financial aspect of independence implies an ability to self-finance and an authorisation of the bank's organs to decide on the allocation of profits, as well as at least the statutory level of regulation in this respect. This is also typically associated with a ban on the central bank lending to the government. The fact that the budget deficit is not financed by the central bank makes it impervious to any pressure from state authorities (especially the executive).

Functionally, the bank's independence entails its exclusive competence to develop and implement the monetary policy. The central bank autonomously sets its goals and chooses the means to achieve them (this discretion is limited only by the law). In the European Union, one aspect of functional independence is institutional independence, meaning that no instructions or orders may be accepted from any other body or institution. ${ }^{4}$

\section{FROM A PRIVATE-PUBLIC BANK TO A MODEL OF GOVERNMENT DEPENDENCY}

In the initial phase of development, central banks were mainly established in the form of capital-based companies. Their position and importance were determined by special privileges, therefore they had a mixed, public-private character. It was no different in the case of a central bank with the longest history - the National Bank of Sweden. Its origins can be traced back to the seventeenth century, when the Riksdag, the Swedish Parliament, ordered the establishment of the Riksens Standens Bank in 1668. Its current name, Sveriges Riksbank, was given only later in 1866 by the King. ${ }^{5}$ In 1897, a law was enacted granting the Swedish National Bank the right to issue banknotes. In 1931, this institution was granted the right to control interest rates. Another bank which is nearly as old is the Bank of England, established in 1694, in the time of wars with France. Initially, its main task was to take care of the State Treasury and manage debts. It started its operation by granting loans to the state in exchange for the right to issue banknotes. ${ }^{6}$ The peak of the bank's importance for the domestic policy of the country dates

\footnotetext{
${ }^{4}$ Ibid.

${ }^{5}$ See http://www.riksbank.se/en/The-Riksbank/History/Money-and-power-the-history-of-Sveriges -Riksbank, accessed June 21, 2017.

${ }^{6}$ H. Gronkiewicz-WALTZ, Bank centralny od gospodarki planowej do rynkowej. Zagadnienia administracyjnoprawne (Warszawa: Centrum Edukacji i Rozwoju Biznesu „Olympus”, 1994), 55.
} 
back to the eighteenth century. At that time, a number of reforms were carried out, which were important for the further development of central banking in England. The bank was granted certain competences with respect to national debt and the depreciation fund. Thanks to its special position in the state and its good relations with the monarch, the bank was the only institution, until mid-nineteenth century, to exist in the form of a limited liability company, which was a unique privilege at the time. ${ }^{7}$ In 1844 , thanks to the so-called Peel Act, the Bank of England was granted the right to issue money. ${ }^{8}$

In turn, the modern Polish central bank traces its history to Polska Krajowa Kasa Pożyczkowa [Polish National Credit Bank], established by a German ordinance of 9 December $1916 .{ }^{9}$ In the early years of its existence, it was the only bank on Polish soil with the right to issue money. The operation of the Polish National Credit Bank took place in a difficult time because Poland had just regained its independence, and the revenues of the Treasury were paltry. The government of the Second Polish Republic, struggling with the problem of consolidating the State's unstable borders and the need to rebuild it after the destructions of war, was forced to borrow funds from other countries - a strategy which kept the state debt increasing. The currency of the time, marka polska [the Polish mark], was quickly losing its value; the growing inflation of 1923 turned into hyperinflation, which was one of the reasons for the decision to liquidate Polska Krajowa Kasa Pożyczkowa and establish Bank Polski [The Bank of Poland] in its place. At the same time, the Polish mark was replaced by the Polish złoty. ${ }^{10}$ The law on the repair of the State Treasure and currency reform ${ }^{11}$ of 1924 , in its Article 1 para. 11 letter $b$, provided for the establishment of a bank of issue under a special charter as a joint-stock bank with State participation. State supervision over this bank boiled down to appointing its president, approving managers and granting the right to issue bank notes. The newly established bank was to receive assets from the already liquidated Polish National Credit Bank. The Bank's charter was granted to it by the ordinance of the President of the Republic of Poland of 20 January 1924 establishing the statute of the bank of

\footnotetext{
${ }^{7}$ See http://www.bankofengland.co.uk/about/Pages/history/default.aspx, accessed June 21, 2017.

${ }^{8}$ J. BRzozowska, Niezależności Narodowego Banku Polskiego na tle historii bankowości, diploma project written under the direction of Dr Zofia Florczak-Nowak, typescript (Warszawa 2002), 14.

${ }^{9}$ Idem, 25.

${ }^{10}$ C. LeszCZyńska, Polska Bankowość Centralna 1828-1989. Bank Polski, Polska Krajowa Kasa Pożyczkowa, Bank Polski SA (Warszawa: Narodowy Bank Polski, 2007), 38.

${ }^{11}$ Journal of Laws of 1924, No. 4, item 28.
} 
issue. ${ }^{12}$ The charter of Bank Polski defines the structure of the Bank, its competencies and relations with state authorities. The Bank's authorities were: the general meeting, president, management board, audit committee and bank council. The exclusive privilege of issuing bank notes was reserved to it only until December 31, 1944.

During the crisis of the 1930s and 1940s, it became noticeable that European countries were increasingly limiting the autonomy of their national banks. This was due to attempts to combat the increasing inflation and the depreciation of national currencies, which the banks could not cope with. Such phenomena could be seen in Poland when, after inflation gave way to hyperinflation, a number of rights vested in the Bank of Poland were transferred to the government. These solutions were also adopted to stabilize the prices in the country and ensure the support of the government in the forthcoming elections. In April 1936, the Bank lost its autonomy completely due to the decree on foreign money trading and foreign and domestic trading of legal tenders. Owing to these solutions, the Polish government was able to redesign the structure of the economy and restore the financial balance caused by the crisis. ${ }^{13}$ During the periods of crisis, an opinion was popular that the central bank was a partner on a equal terms with the government with respect to financial policy. It was believed that the bank should pursue its financial policy in a way which did not jeopardise the stability of prices in the country. ${ }^{14}$

After the Second World War, central banks underwent further subordination to the economic policies of central governments. Many banks, previously operating as companies (including the Bank of England), were nationalized. At that time, it was perceived as an institution performing tasks delegated by the government rather than creating its own policy. In addition, the freedom of operation of central banks was limited by the principles of the Bretton Woods system. ${ }^{15}$ In the situation when the world currency system rested on

\footnotetext{
${ }^{12}$ Journal of Laws of 1924, No. 8, item 75.

${ }^{13}$ C. LeszCZyŃska, Zarys Polskiej Bankowości Centralnej (Warszawa: Narodowy Bank Polski, 2010), 32.

${ }^{14}$ GRONKIEWICZ-WALtZ, Bank centralny, 36.

${ }^{15}$ Established at an international conference in 1944, the currency system was based on a gold standard and fixed exchange rates. Each currency unit was assigned a value equal expressed in the weight of gold. Fixed exchange rates were set against the dollar, which was the only currency convertible into gold. The International Monetary Fund became an organisation responsible for the functioning of the monetary system. It was the task of the national central banks to maintain the convertibility of their currencies into the dollar at a fixed exchange rate (fluctuations of no more than $1 \%$ were allowed, and no more than $2.25 \%$ as of 1971 ); see W. RuTKOWSKI, Między-
} 
a gold standard, the freedom of issuing policy practically did not exist, the volume of money was strictly dependent on gold and currency reserves in possession. Exchange rate fixation expressly defined the bank's role as the guardian of the value of the currency, which was obliged to conduct open market operations-buying and selling currencies in order to maintain the assumed exchange rate. ${ }^{16}$

In the 1980s, the competence of central banks and their independence from governments increased. The perception of central banking was influenced by the ongoing processes of European integration and problems of the global economy, the oil crisis and the collapse of the Bretton Woods system. The document worth mentioning was the 1970 Werner report, ${ }^{17}$ which put forward a proposal for a community system of central banks to be created, independent of the governments of the Member States. ${ }^{18}$ This concept underwent further development until 1989, when the Delors Report was compiled. ${ }^{19}$ At the time, it was recognised that it was virtually impossible to supervise the monetary policy of most European countries, and therefore it became necessary to introduce a single monetary policy through monetary union. The European Central Bank, as a body carrying the burden of conducting such a uniform monetary policy, would need to have the exclusive right to issue money available in the Union. The creation of such an institution would require the countries resolving to join that monetary union to transfer some of their monetary policy powers to the European Central Bank [hereafter ECB]. Otherwise, it would not be possible for the ECB to pursue a uniform policy without having the appropriate instruments to coordinate all its activities. At the planning stage, the principle was adopted that budget deficit cannot be compensated by means of loans from the central bank. The member banks should also be independent of governments. ${ }^{20}$

narodowy System Walutowy - możliwości nowych rozwiazań, Brochure no. 753 (Warszawa: Kancelaria Sejmu, Biuro Studiów i Ekspertyz, 2000), 1-2.

${ }^{16}$ Ibid.

${ }^{17} \mathrm{P}$. WeRner, "Report to the Council and the Commission on the realisation by stages of Economic and Monetary Union in the Community- 'Werner Report' (definitive text)," Bulletin of the European Communities, Supplement 11 (1970).

${ }^{18} \mathrm{~K}$. SZELĄG, Integracja walutowa $w$ Europie Zachodniej w okresie powojennym (Warszawa: Narodowy Bank Polski, 2003), 14.

${ }^{19}$ Report on Economic and Monetary Union in the European Community, Committee for the Study of Economic and Monetary Union, April 1989.

${ }^{20}$ Ibid. 
The premises of Delors' plan were reflected in the Maastricht Treaty. ${ }^{21}$ The European Central Bank became the kingpin of the European system of central banks. Its governing body was to be the Governing Council, composed of the ECB's executive board and the presidents of the central banks of twelve Member States. The bank was to be entrusted with the exclusive competence to formulate objectives and implement monetary policy. Personal autonomy was guaranteed by, among others, long, eight-year terms of office of the bank's presidents and other members of its governing council. Under Article 109a, the president, vice-presidents and the other members of the executive board were elected by common accord of the Member State governments at the highest European decision-making level of heads of state or government, on a recommendation from the Council and after consulting the European Parliament and the Council of the ECB. Getting the most important institutions involved in the decision process necessitated a consensus and strengthened the mandate of the Executive Board. Only persons with a recognised authority and professional monetary and banking experience could be elected. It was not possible to renew the mandate (Article 109a(2) of the Maastricht Treaty). This solution would strengthen the independence of the governing board, as otherwise there could be some degree of subservience to the more influential Member States, which would seek re-election.

The solutions adopted at the European level led to legislative changes in European countries. Changes also occurred in the countries indicated above, namely England and Sweden. This is all the more interesting and clearly shows the trend that occurred in the development of central banking at that time, since these countries ultimately did not join the monetary union. The Swedish central bank is guaranteed independence by virtue of Chapter IX of the Swedish constitution entitled "Financial Authority." The guarantees were introduced by the act no. 1402 of $1998 .^{22}$ In accordance with Chapter $9 \S 12$ of the Constitution of the Kingdom of Sweden concerning financial authority, the Bank of Sweden is linked with the Swedish parliament. The Riksdag elects 11 commissioners, who elect the members of the governing board. The commissioners also remove board members from office, but this is only possible in cases of gross negligence or when they are unable to perform their duties due to, for example, health reasons. The control of the Riksdag over the bank is exercised by way of an annual vote of approval regarding each commissioner. Failure to obtain that results in resignation from the

\footnotetext{
${ }^{21}$ OJ C 191, 29.7.1992.

${ }^{22}$ See http://libr.sejm.gov.pl/tek01/txt/konst/szwecja-a1r9.html, accessed June 21, 2017.
} 
office. The Swedish cnstitution guarantees the Bank of Sweden the exclusive right to issue banknotes and coins and its independence from other institutions.

Operational independence and freedom to determine interest rates was granted to the Bank of England in 1998 by the Bank of England Act. ${ }^{23}$ This law defined the role of the Bank of England as a monetary authority, the state bank, and a financial system supervisor (Part II, 10). The following objectives of the bank were specified: to maintain price stability and support the government's economic policy (Part II, 11). A key role in the management of the bank is played by the court of directors, which spells out the bank's objectives and strategy as well as managing its reserves (Part I, 2). It is composed of a governor and his three deputies, who are appointed for a five-year term by Her Majesty's Royal Highness on a joint proposal of the Prime Minister and Chancellor, and up to nine non-executive directors, whose term of office is three years, appointed under the same procedure (Part I, 1-1A).

\section{THE RISE OF INDEPENDENT CENTRAL BANKING IN POLAND}

Until 1982, the president of Narodowy Bank Polski [National Bank of Poland/NBP] would be appointed by the Council of Ministers upon the motion of the Minister of Finance. This gave the president and the Bank itself a low rank in the State. The NBP had no independence in the area of monetary policy. Therefore, the design of the banknotes and the nominal value of money were set by the Minister of Finance at the request of the president of the NBP. The vice-presidents were appointed by the Council of Ministers upon a proposal agreed by the Minister of Finance and the president of the NBP. Members of the management board were also appointed by the Council of Ministers upon the motion of the Minister of Finance (to which the motion was submitted by the president of the NBP). At that time it was a bank functionally subordinated to the Council of Ministers, or rather to the Minister of Finance, which prevented the bank from conducting its own independent monetary policy. ${ }^{24}$ The consolidation, at least symbolically, of

\footnotetext{
${ }^{23}$ See http://www.legislation.gov.uk/ukpga/1998/11/contents, accessed June 21, 2017.

${ }^{24}$ Articles 21 and 25 of the Banking Act of 12 June 1975, Journal of Laws No. 20, item 108. W. KAPUŚCIŃSKA, "Dwudziestolecie polityki pieniężnej NBP. Wpływ transformacji i integracji gospodarczej," Ruch Prawniczy, Socjologiczny i Ekonomiczny 71, no. 2 (2009): 281.
} 
the NBP's position started in 1982, when the rules for appointing its president and vice-presidents were amended. ${ }^{25}$ From then on, the president was appointed by the Sejm on the motion of the Prime Minister. In turn, the vice-presidents were appointed by the Prime Minister upon the motion of the NBP president. Thus, the appointment of the Bank's authorities became much more important.

Act of 31 January 1989 on the National Bank of Poland ${ }^{26}$ still left the NBP functionally dependent on the government. The monetary and foreign exchange policy was conducted in agreement with the government, which had the decisive vote in these matters. The exchange rates were set by the president of the NBP in consultation with the Finance Minister. As regards the financial economy, NBP was not independent, either-the Council of Ministers examined and approved the Bank's balance sheet. ${ }^{27}$

The concept of NBP's independence was first introduced in Poland in $1992 .{ }^{28}$ At that time, the procedure for the election of the NBP president was introduced, consisting in the Sejm approving a candidate nominated by the President. On the one hand, this meant a higher rank, but on the other hand it required that a candidate should be found who would be accepted by both the head of state and the legislature. ${ }^{29}$ The National Bank of Poland was then granted freedom in its formulation of prudential norms and control of capital flows. In 1996, the NBP gained freedom in shaping the operational objectives of its monetary policy. ${ }^{30}$

The full implementation of the concept of an independent central bank in Poland was vested in the Constitution of $1997^{31}$ and the Act on the National Bank of Poland of 29 August $1997^{32}$ [henceforth abbreviated as ANBP]. The Constitution of 1997 introduced and guaranteed strong independence of the central bank, while its dispositional provisions were developed in detail in the Act.

Personnel independence was manifested by the procedure of appointing the Bank's organs, which required cooperation between the representatives

\footnotetext{
${ }^{25}$ Journal of Laws of 1982, No. 7, item 56.

${ }^{26}$ Journal of Laws of 1989, No. 4, item 22.

${ }^{27}$ LesZCZYŃSKA, Polska Bankowość Centralna, 39.

${ }^{28}$ Act of 14 February 1992 amending the Banking Law and certain other acts, Journal of Laws No. 20, item 78.

${ }^{29}$ KAPUŚCIŃSKA, Dwudziestolecie polityki pieniężnej NBP, 282.

${ }^{30}$ LesZCZYŃska, Zarys Polskiej Bankowości Centralnej, 57.

${ }^{31}$ Journal of Laws of 1997 , No. 78, item 483.

${ }^{32}$ Journal of Laws of 1997, No. 140, item 938.
} 
of two authorities: the executive and legislative (this demonstrates the lack of subordination of either of them), as well as the impossibility of arbitrary dismissal of persons holding functions in these organs. The existing procedure was maintained. The Government and the Minister of Finance do not have any influence on the staffing of NBP organs. Competencies in this area are shared by the Sejm, Senate and the President (Article 227 para. 5 of the Constitution). The inclusion of both the state legislative authority and the head of State in the procedures for the appointment of NBP officers strengthens the mandate of the Bank's authorities, enforces a kind of political consensus and fosters the pluralistic composition of the Monetary Policy Council. Pursuant to Article 227 para. 3 of the Constitution and Article 9 of the act on NBP, the Bank's president is appointed by the Sejm upon the motion of the President, which requires that the President nominates such a candidate to be approved by the Sejm. Such a solution favours the search for a compromise and the selection of a candidate who is well prepared in terms of expertise, especially if the head of state is affiliated with a different political option than the parliamentary majority. A symbolic manifestation of the independence of the president of the NBP is his or her swearing an oath before the Sejm and the solemnity of its form.

Three authorities choose the members of the Monetary Policy Council in equal numbers: the Sejm, Senate and President (Article 227 para. 5 of the Constitution and Article 13 ANBP). It is worth noting that the current political practice of the Third Polish Republic as regards the staffing of the Bank's organs deserves a positive appraisal. The candidates are people with extensive knowledge of the economy, usually professors of economic sciences. This is why this NBP organ has retained its expert character for the past 20 years. This is reflected by the internal divisions within the Council related to differing views on monetary policy (mild or restrictive) rather than political sympathies. ${ }^{33}$ The president of the NBP has a decisive role in the staffing of the management board, presenting his/her selection of candidates for vice-presidents to the President (Article 17 ANBP).

The independence and proper performance of functions by the president of NBP is guaranteed by the ban on membership in any political party, trade union or any public activity which is incompatible with the dignity of the office held (Article 227 para. 4 of the Constitution). A similar ban, albeit no longer of constitutional but rather of statutory importance, can be found in

\footnotetext{
${ }^{33}$ Compare Dostosowywanie polskiego systemu bankowego do standardów Unii Europejskiej, ed. A. Pomorska (Lublin: Wydawnictwo Uniwersytetu Marii Curie-Skłodowskiej, 1999), 49.
} 
Article 14 para. 2 ANBP. Members of the Monetary Policy Council must suspend their activities in a party or trade union for the duration of their term of office. Failure to observe this restriction is a reason for dismissal from the Council. In addition, the Council members may not hold any other positions or undertake any gainful or public activity other than scientific, didactic or authorial work (Article 14 para. 1 ANBP). The Council may give consent to taking up positions international organisations.

Holders of positions with the NBP may be recalled only in the cases and manner specified by ANBP. Members of the management board report to the president of the NBP, who submits to the President a motion for their appointment or dismissal. Without the motion of the NBP's president, the President may not in any way interfere in the composition of the management board. The act provided a closed catalogue of circumstances in which the president of the NBP can be dismissed, limited to only four cases:

- breach of duty due to a prolonged illness

- a conviction by a final judgement of committing a crime

- submitting an incorrect lustration declaration, confirmed by a final court decision

- a decision of the State Tribunal prohibiting the exercise of managerial positions or functions entailing special responsibilities in State organs (Article 9 para. 5 ANBP).

Also, members of the Monetary Policy Council can be dismissed only in exceptional cases:

- an illness permanently preventing the exercise of functions

- submitting an incorrect lustration declaration, confirmed by a final court decision

- a final conviction of a criminal offence

- breach of the ban on incompatibility (Article 13 para. 5 ANBP).

The NBP's financial independence is reflected in its ability to self-finance and the competence to decide on the use of profits. The principles of NBP's financial management are specified in Articles 60-70 ANBP. The Bank's own funds were divided into a statutory fund and a reserve fund. Article 61 of the act set the amount of the statutory fund at PLN 1.5 billion. The reserve fund was to be created from the NBP profit write-offs, made within 14 days from the date when the NBP financial statements are approved, until the fund reaches the equivalent of the statutory fund. ${ }^{34}$ The

\footnotetext{
${ }^{34}$ A. Mikos, Ustrojowa pozycja banku centralnego w Polsce (Warszawa: Wydawnictwo C.H. Beck, 2006), 121.
} 
amount of such write-offs was established at $5 \%$ of the annual profit. Article 62 specified the possibility of using the reserve fund only to cover balance sheet losses of the NBP.

The audit of the annual financial statement has become practically the only control competence of the Council of Ministers with respect to the NBP. The president of the NBP is to present it to the government by 30 April of the year following the fiscal year. The Council of Ministers, however, takes a decision on its approval. However, it should be noted that a lack of approval does not entail consequences for the rights and obligations of the central bank. Even before it is submitted to the Council of Ministers, the report is audited by a certified auditor appointed by the Monetary Policy Council-so we speak of an element of internal control here. Article 69 ANBP specifies the period of 14 days from the date when the annual financial statement is approved to the payment of the annual profit to the State budget by the Bank. The amount of this payment is decided by the NBP management board. No vote of approval is taken on the NBP management board should it fail to make planned payments to the State budget (e.g. due to unreasonable losses). ${ }^{35}$

With respect to functional independence, the Constitution and the Act on the NBP guaranteed the Bank the exclusive right to issue money and to determine and implement a monetary policy. The Bank presents the assumptions of the monetary policy to the Sejm for its information only. No other authority has been authorised to act on this matter. ${ }^{36}$ The provisions of Articles 31-37 ANBP guaranteed the exclusive competence of the president of the NBP with respect to the issue of cash.

The independence of the National Bank of Poland was also strengthened by the provision of Article 5 para. 2 ANBP prohibiting it from holding shares in other legal persons, except for those providing services to financial institutions, the State Treasury or those that are relevant for the NBP in terms of maintaining the stability of the national financial system. The purpose of this ban is to prevent potential conflicts of interest and attempts to put pressure on the Bank's authorities to engage in enterprises for purposes other than those for which the Bank itself was established (e.g. politically important investments).

\footnotetext{
${ }^{35}$ Ibid.

${ }^{36}$ See the Judgement of the Constitutional Tribunal of 16 July 2017, file ref. no. Kp 4/08, OTK ZU of 2009, no. 7A, item 112.
} 
The Act on the NBP clearly emphasized the informative character of the competences of State executive and legislative authorities in relation to the elected NBP governing bodies. Pursuant to Article 21 of the Act, the NBP presents the assumptions of its policy and information on its implementation to the state authorities. There's no question of agreeing or approval. Pursuant to Article 70 ANBP and Article 227 para. 6 of the Constitution, the NBP president is obliged to present an annual report on the activities of the Bank to the Sejm within 5 months of the end of the financial year. The Act did not provide for a vote on this report.

\section{CONCLUSION}

In the initial phase of their development, central banks were mainly established as capital-based companies. Their position and importance were determined by special privileges. Until the end of the 1920 s, their position and independence from the state authorities were strengthened. During the interwar period, the public character of central banks was also reinforced. Bank Polski enjoyed a far-reaching independence shortly after its establishment in 1924. Later, however, this independence was significantly impaired by the authorities of the Second Polish Republic, which was associated with a decline in the importance of this institution and attempts to subordinate it to the government. Dependence on the government and the lowered rank and position of the central bank was characteristic of European countries after World War II and was connected with the concepts concerning the functioning of the world economy adopted at that time, including the monetary system (the Bretton Woods Agreement). The position of the Polish central bank after the Second World War was also limited, although for completely different reasons. When, after 1989, Poland started to draw on the political models of the western countries again, there was a clear trend towards independence and strengthening of the position of the central bank. It is worth mentioning that the process of European integration was crucial for the adoption and formation of the paradigm of an independent central bank. The normative act that exerted major influence on the shape of the nowadays dominant concept of an independent central bank, conducting free monetary policy as it sees fit, was the Maastricht Treaty. It contains several principles whereby the central banks of European countries were reformed in the following years. 
The reforms implemented since 1989 gradually strengthened the independence of the NBP until the Constitution of the Republic of Poland was promulgated in 1997, in which the concept of an independent central bank was fully adopted. The State's political practice turned it into an institution which strongly relies on experts. The position of the NBP, consolidated in 1997, was now fully in line with the Euro-Atlantic paradigm of an independent central bank.

\section{BIBLIOGRAPHY}

\section{SOURCES OF LAW}

Ustawa z dnia 11 stycznia 1924 r. o naprawie Skarbu Państwa i reformie walutowej [Act of 11 January 1924 on the repair of State Treasury and currency reform]. Journal of Laws No. 4, item 28.

Rozporządzenie Prezydenta Rzeczypospolitej z dnia 20 stycznia 1924 r. w przedmiocie ustanowienia statutu dla banku emisyjnego [Ordinance of the President of the Republic of Poland of 20 January 1924 establishing the statute of the bank of issue]. Journal of Laws No. 8, item 75.

Constitution of the Republic of Poland of 2 April 1997. Journal of Laws No. 78, item 483, as amended.

Ustawa z dnia 29 sierpnia 1997 r. o Narodowym Banku Polskim [Act on 29 August 1997 on the National Bank of Poland]. Journal of Laws No. 140, item 938.

Ustawa z dnia 26 lutego 1982 r. - Prawo bankowe [The Banking Act of 29 August 1997]. Journal of Laws No. 7, item 56.

Ustawa z dnia 31 stycznia 1989 r. o Narodowym Banku Polskim [Act of 31 January 1989 on the National Bank of Poland]. Journal of Laws No. 4, item 22.

Treaty on European Union. OJ C 191, 29.7.1992.

\section{CASE LAW}

Judgement of the Constitutional Tribunal of 17 July 2017, file ref. no. Kp 4/08. OTK ZU of 2009, no. $7 \mathrm{~A}$, item 112 .

\section{LITERATURE}

BLINDER, Alan. Bankowość centralna w teorii i praktyce. Warszawa: Wydawnictwo: CeDeWu, 2001.

BrzozowsKa, Joanna. Niezależności Narodowego Banku Polskiego na tle historii bankowości, diploma project written under the direction of Dr Zofia Florczak-Nowak, typescript. Warszawa 2002.

Dostosowywanie polskiego systemu bankowego do standardów Unii Europejskiej, edited by Alicja Pomorska. Lublin: Wydawnictwo Uniwersytetu Marii Curie-Skłodowskiej, 1999. 
GronKIEWICZ-WALTZ, Hanna. Bank centralny od gospodarki planowej do rynkowej. Zagadnienia administracyjnoprawne. Warszawa: Centrum Edukacji i Rozwoju Biznesu "Olympus," 1994.

KAPUŚCIŃSKA, Wiesława. "Dwudziestolecie polityki pieniężnej NBP. Wpływ transformacji i integracji gospodarczej." Ruch Prawniczy, Socjologiczny i Ekonomiczny 71, no. 2 (2009): 279-97.

LeszCzyńska, Cecylia. Polska Bankowość Centralna 1828-1989. Bank Polski, Polska Krajowa Kasa Pożyczkowa, Bank Polski SA. Warszawa: Narodowy Bank Polski, 2007.

LeszCzyŃska, Cecylia. Zarys Polskiej Bankowości Centralnej. Warszawa: Narodowy Bank Polski, 2010.

MARSZAŁeK, Paweł. Koordynacja polityki pieniężnej i fiskalnej jako przestanka stabilności cen. Warszawa: Wydawnictwo Naukowe PWN, 2009.

Mikos, Agnieszka. Ustrojowa pozycja banku centralnego w Polsce. Warszawa: Wydawnictwo C.H. Beck, 2006.

MyŚlaK, Ewa. Narodowy Bank Polski w systemie ustrojowym Rzeczypospolitej Polskiej. Kraków: Wydawnictwo Uniwersytetu Jagiellońskiego, 2013.

RUTKOwSKI, Witold. Międzynarodowy System Walutowy—możliwości nowych rozwiąań, Brochure 753. Warszawa: Kancelaria Sejmu, Biuro Studiów i Ekspertyz, 2000.

SZELĄG, Konrad. Integracja walutowa w Europie Zachodniej w okresie powojennym. Warszawa: Narodowy Bank Polski, 2003.

\section{INTRODUCTION OF THE CONCEPT OF CENTRAL-BANK INDEPENDENCE INTO THE POLISH POLITICAL SYSTEM IN LIGHT OF THE EUROPEAN EXPERIENCE}

\section{Summary}

The article is intended to outline the development of central banking in terms of its independence, with particular emphasis on the implementation of the idea of an independent central bank in Poland, also comparison with some other countries. The idea of central-bank independence was presented from personnel, financial and functional perspectives.

In the initial phase of their development, central banks were mainly established in the form of capital-based companies. Their position and importance was determined by special privileges. The Maastricht Treaty was a normative act that had a major influence on the shape of the currently dominant concept of an independent central bank, which pursues a free monetary policy at its own discretion. The Constitution of 1997 and the Act 29 August 1997 on the National Bank of Poland of were crucial in guaranteeing the strong position and independence of NBP from state authorities.

Key words: central bank; independence; monetary policy; staffing of bank authorities.

Translated by Tomasz Patkowski

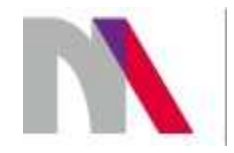

The preparation of the English version of Roczniki Nauk Prawnych (Annals of Iuridical Sciences) and its publication in electronic databases was financed under contract no. 836/PDUN/2018 from the resources of the Minister of Science and Higher Education for the popularization of science. 